\title{
Kualitas Audit Moderasi Antara Komite Audit Dan Nilai Perusahaan
}

\author{
AL JUFRI \\ Universitas Lancang Kuning \\ Jln. Yos Sudarso KM 08 Rumbai Telp. (0761) 52581 \\ E-mail : eri_jufri@yahoo.co.id
}

\begin{abstract}
Each company aims to prosper shareholders by increasing the value of the company. The Audit Committee is an important component that every company needs to pay attention to. The purpose of this study is to determine the effect of audit committees on firm value and audit quality as variables that moderate audit committee relationships and firm value. Object of research of Manufacturing Company of Basic and Chemical Industry sub sector listed in BEI year 2016. Research method by using quantitative analysis with linear regression analysis with moderating variable. Quantitative analysis is conducted for annual data for 2 Years (2013-2014). The results of the Audit Committee) have no significant effect on the value of the company either as well as the quality of the audit is not a variable that can moderate the audit committee relationship and the value of the company.
\end{abstract}

Keywords: Company Value, Audit Committee and Audit Quality

Komite audit sebagai salah satu unsur Good Corporate Governance, memegang peranan yang cukup penting dalam mewujudkan Good Corporate Governance (Effendi, 2005 dalam Aljufri 2013). Tugas pokok dari komite audit pada prinsipnya adalah membantu Dewan Komisaris dalam melakukan fungsi pengawasan atas kinerja perusahaan. Hal tersebut terutama berkaitan dengan review sistem pengendalian intern perusahaan, memastikan kualitas laporan keuangan, dan meningkatkan efektivitas fungsi audit. Melihat fungsi dan tugas audit yang merupakan fungsi yang esensial maka keberadaan komite audit yang melaksanakan fungsi dan tugasnya dengan baik menjadi sangat penting sebagai salah satu perangkat utama dalam penerapan prinsip akuntabilitas, transfaransi dari corporate governance sehingga tujuan perusahaan tercapai yang berarti nilai perusahaan juga meningkat.

Klein (2002), dan Xie et al (2003) dan Aljufri 2013, membuktikan pentingnya keberadaan komite audit dalam membatasi manajemen laba sehingga laporan keuangan yang disajikan secara wajar dapat menunjukan bahwa manajer menjalankan prinsip kewajaran sebagai prinsip dari
Good Corporate Governance yang diharapkan akan meningkatkan nilai perusahaan. Chan and Li. (2008), Abdullah et al (2008) menemukan hubungan positif dan signifikan antara komite audit dan nilai perusahaan. Namun Rachmawati dan Triatmoko (2007) tidak menemukan hubungan antara komite audit dan nilai perusahaan. Perbedaan ini menimbulkan pertanyaan apakah keberadaan komite audit sebagai impelementasi Good Corportae Governance dapat benar-benar meningkatkan nilai perusahaan.

Berdasarkan hasil penelitian di atas mengenai hubungan komite audit terhadap nilai perusahaan yang tidak konsisten menandakan ada faktor lain yang menginteraksi hubungan tersebut. Hal ini mendorong penulis mencoba memasukkan faktor lain yang dapat memoderasi hubungan antara komite audit terhadap nilai perusahaan. Dalam hal inilah penulis mencoba membuktikan apakah kwalitas audit (yang diproksi dengan ukuran Kap yang diukur dengan big-4) memoderasi hubungan Corporate Governance terhadap nilai perusahaan. 
Penelitian De Angelo (1981 dalam Aljufri 2013) mengemukakan bahwa KAP yang besar memiliki insentif yang lebih untuk menghindari hal-hal yang dapat merusak reputasinya dibandingkan dengan KAP yang lebih kecil. Argumen tersebut menggambarkan bahwa KAP yang besar memiliki independensi yang lebih tinggi dibanding auditor KAP yang lebih kecil sehingga audit yang dilakukannya akan menghasilkan audit yang berkualitas. Disamping KAP yang besar menghasilkan audit yang berkwalitas maka sikap independensi yang dimiliki KAP yang besar tersebut tentu akan menghindari konflik kepentingan karena merasa tidak ada manfaat baginya jika KAP yang besar tersebut memilih kepentingan salah satu fihak.

Hal ini tentunya akan dapat mempengaruhi agen mengelola perusahaan sesuai tujuan perusahaan melalui pelaporan keuangan yang disusun sesuai prinsip akuntansi yang berlaku umum. Selain itu KAP yang besar sebagai fihak yang independen juga sangat diperlukan karena audit yang dilakukannya didasarkan pada kepercayaan pemakai jasa auditor bahwa auditor memiliki kekuatan monitoring yang secara umum tidak dapat diamati. Secara umum peran KAP baik besar maupun kecil adalah memberikan keyakinan atas kualitas informasi keuangan dengan memberikan pendapat yang independen atas kewajaran penyajian informasi dalam laporan keuangan. Adanya kewajaran laporan keuangan dapat mempengaruhi investor untuk membeli atau menarik sahamya pada sebuah perusahaan yang juga akan dapat meningkatkan nilai perusahaan.

Tetapi pada tabel 1 komite audit belum dapat memaksimalkan nilai perusahaan yang disebabkan beberapa masalah.
Tabel 1. Rata-Rata NP, DK, KI, KA Pada Perusahaan Manufaktur (Subsektor Industri Dasar dan Kimia Tahun 2013-2014

\begin{tabular}{|l|c|c|}
\hline & 2013 & 2014 \\
\hline $\begin{array}{l}\text { Nilai } \\
\text { Perusahaan }\end{array}$ & 1,79 & 1,26 \\
\hline $\begin{array}{l}\text { Komite } \\
\text { Audit }\end{array}$ & 3,11 & 3,15 \\
\hline
\end{tabular}

Tinjauan Pustaka ini akan mengemukakan beberapa penjelasan dan teori dari beberapa ahli. Sebelum mencapai pada permasalahan yang sedang dihadapi oleh perusahaan sesungguhnya, perlu dikemukakan beberapa teori yang prinsipal sebagai langkah pendekatan terhadap pemecahan masalah di samping pemecahan masalah bukan teori.

Hasil penelitian tentang hubungan komite audit dan nilai perusahaan tidak konsisten. Rachmawati dan Triatmoko (2007 dengan menggunakan sampel 190 perusahaan manufaktur yang terdaftar di Bursa Efek Jakarta selama periode 20012005 tidak menemukan pengaruh komite audit terhadap nilai perusahaan. Namun Weir et al (2003) dalam Aljufri (2013), Siallagan dan Machfoedz (2006), Chan and Li (2008), Abdullah et al (2008) menemukan bahwa komite audit independen berpengaruh signifikan dan positif terhadap nilai perusahaan.

KAP Big 4 yang merupakan kantor akuntan yang mempunyai reputasi dan memiliki independensi yang merupakan KAP yang berkualitas. Penyataan ini dikuatkan oleh De Angelo (1981 dalam Aljufri 2013), yang menyatakan bahwa kwalitas audit yang diukur dengan auditor skala besar memiliki insentif yang lebih untuk menghindari kritikan kerusakan reputasi dibandingkan pada auditor skala kecil. Argumen tersebut berarti bahwa auditor skala besar memiliki independensi yang lebih tinggi dibanding auditor berskala kecil sehingga dapat mendorong komite audit bertindak membantu komisaris melakukan fungsi pengawasan dan pemberian nasehat berdasarkan 
informasi dari laporan keuangan yang berkualitas sehingga nilai perusahaan naik. Oleh sebab itu, semakin tinggi kualitas audit, semakin kuat kemungkinan komite audit membantu komisaris melakukan pengawasan kepada direksi. Sehingga hubungannya positif antara kualitas audit dan komite audit ini dapat memperkuat pengaruh antara komite audit dan nilai perusahaan.

Suatu perusahaan dikatakan memiliki nilai yang baik jika kinerja perusahaan juga baik dan tercermin dari harga saham yang tinggi. Nilai perusahaan dapat ditingkatkan dengan meningkatkan kinerja perusahaan. Salah satu caranya adalah dengan menerapkan praktik tata kelola perusahaan yang baik. Dalam penelitian ini, variabel dependen diukur dengan nilai Tobin's Q. Tobin's Q memiliki manfaat tersendiri dalam merefleksikan nilai perusahaan dan potensial profitabilitas perusahaan dimasa mendatang (Ruan et al. 2011). Tobin's Q diukur dengan perhitungan nilai pasar ekuitas ditambah dengan nilai buku utang jangka pendek dan nilai buku utang jangka panjang dibagi dengan total asset (Kumar dan Singh, 2013).

\section{METODE}

Objek Penelitian ini adalah Komite Audit, Kualitas Audit dan Nilai Perushaan pada perusahaan manufaktur industri dasar dan kimia yang tedaftar di BEI periode 2013-2014. Jenis data yang digunakan adalah data sekunder seperti laporan tahunan dan laporan keuangan 2 Tahun (2013- 2014) yang terdiri dari neraca dan laporan laba rugi serta data lain yang berhubungan dengan penelitian seperti jurnal ilmiah, laporan hasil penelitian, majalah dan publikasi lainnya.

Teknik pengumpulan data dari studi dokumentasi terhadap dokumen-dokumen yang berkaitan dengan masalah yang diteliti. Adapun dokumen yang diamati adalah laporan tahunan dan laporan keuanagan .

Pendekatan yang digunakan dalam penelitian ini adalah penelitian kausal komparatif (causal comparative research) dengan Varibel Moderating. Penelitian ini menggunakan model sebagai berikut :

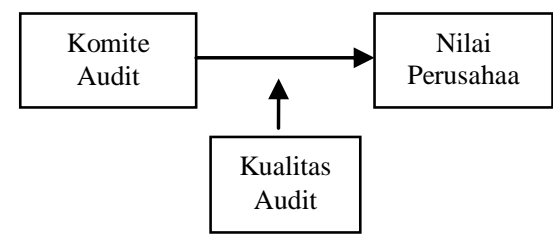

HASIL

1. Uji F

Tabel 7. Hasil Uji F dengan Anova (F-test)

ANOVA $^{\text {b }}$

\begin{tabular}{|l|l|l|l|l|l|}
\hline Model & $\begin{array}{l}\text { Sum of } \\
\text { Squares }\end{array}$ & df & $\begin{array}{l}\text { Mean } \\
\text { Square }\end{array}$ & F & Sig. \\
\hline 1 Regression & 2.226 & 2 & 1.113 & .302 & $.741^{\mathrm{a}}$ \\
Residual & 188.104 & 51 & 3.688 & & \\
Total & 190.330 & 53 & & & \\
\hline
\end{tabular}

a. Predictors: (Constant), KA, Kwa

b. Dependent Variable: absnp

\section{Uji t}

Tabel 8. Hasil Uji t dengan coefficients ${ }^{\mathrm{a}}$ (ttest)

\section{Coefficients $^{\text {a }}$}

\begin{tabular}{|c|c|c|c|c|c|}
\hline \multirow[b]{2}{*}{ Model } & $\begin{array}{l}\text { Unst } \\
\text { zed } \\
\text { Coef }\end{array}$ & $\begin{array}{l}\text { tandardi } \\
\text { fficients }\end{array}$ & $\begin{array}{l}\text { Standardi } \\
\text { zed } \\
\text { Coefficien } \\
\text { ts }\end{array}$ & \multirow[t]{2}{*}{ 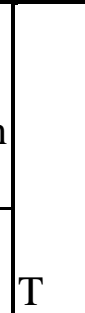 } & \multirow[b]{2}{*}{ Sig } \\
\hline & B & $\begin{array}{l}\text { Std. } \\
\text { Error }\end{array}$ & Beta & & \\
\hline $\begin{array}{c}1 \text { (Consta } \\
\mathrm{nt})\end{array}$ & $\begin{array}{l}1.90 \\
5\end{array}$ & 1.783 & & $\begin{array}{l}1.06 \\
8\end{array}$ & $\begin{array}{l}.29 \\
0\end{array}$ \\
\hline KA & -149 & .557 & -.038 & -2 & $\begin{array}{l}.79 \\
0\end{array}$ \\
\hline Kwa & .467 & .679 & .097 & .688 & $\begin{array}{l}.49 \\
4\end{array}$ \\
\hline
\end{tabular}

a. Dependent Variable: NP

Sumber : Pengolahan data SPSS

3. Uji Interaksi

Tabel 9. Hasil Uji Interaksi 


\begin{tabular}{|c|c|c|c|c|c|}
\hline \multirow[b]{2}{*}{ Model } & $\begin{array}{l}\text { Uns } \\
\text { zed } \\
\text { Coe }\end{array}$ & $\begin{array}{l}\text { tandardi } \\
\text { fficients }\end{array}$ & $\begin{array}{l}\text { Standardi } \\
\text { zed } \\
\text { Coefficie } \\
\text { nts }\end{array}$ & \multirow[b]{2}{*}{$\mathrm{t}$} & \multirow[b]{2}{*}{ Sig } \\
\hline & B & $\begin{array}{l}\text { Std. } \\
\text { Error }\end{array}$ & Beta & & \\
\hline $\begin{array}{l}1 \text { (Consta } \\
\mathrm{nt})\end{array}$ & $\begin{array}{l}1.9 \\
05\end{array}$ & 1.783 & & $\begin{array}{l}1.06 \\
8\end{array}$ & $\begin{array}{l}.29 \\
0\end{array}$ \\
\hline $\mathrm{KA}$ & $\begin{array}{l}- \\
.14 \\
9\end{array}$ & .557 & -.038 &. & $\begin{array}{l}.79 \\
0\end{array}$ \\
\hline $\begin{array}{l}\text { Modera } \\
\mathrm{t}\end{array}$ & 6 & .226 & .097 & .688 & $\begin{array}{l}.49 \\
4\end{array}$ \\
\hline
\end{tabular}

\section{PEMBAHASAN}

Hasil penelitian ini membuktikan ukuran komite audit tidak berpengaruh terhadap nilai perusahaan. Hal ini berarti keberadaan komite audit hanya sebatas formalitas untuk memenuhi peraturan pemerintah saja tetapi tidak dimaksudkan untuk menegakkan mekanisme good corporate governance dalam perusahaan. Sebagaimana yang dijelaskan oleh Effendi (2009), pengangkatan komite audit di perusahaan publik tidak didasarkan pada kemampuan dan kompetensi yang dimiliki, namun lebih didasarkan pada hubungan dengan dewan komisaris independen, sehingga kinerja komite audit kurang optimal dalam melakukan fungsi pengawasan terhadap kinerja manajemen. Oleh karena itu, besar kecilnya jumlah komite audit di perusahaan tidak dapat meningkatkan nilai perusahaan. Namun hasil penelitian ini sejalan dengan temuan Rachmawati dan Triatmoko (2007) yang juga tidak menemukan pengaruh komite audit terhadap nilai perusahaan.

Hasil penelitian ini juga tidak menemukan bahwa Kwalitas audit yang diproksi dengan Ukuran KAP (big 4) tidak dapat memoderasi hubungan Komite Audit terhadap nilai perusahaan. Hal ini mungkin Ukuran KAP bukan merupakan proxy yang baik untuk kualitas audit di Indonesia. Siregar dan Utama (2005).

\section{SIMPULAN}

Berdasarkan hasil penelitian dan pembahasan yang telah dijelaskan sebelumnya, maka simpulan yang dapat diambil dari penelian ini adalah : Ukuran komite audit tidak berpengaruh terhadap nilai perusahaan, berarti keberadaan komite audit hanya sebagai formalitas untuk memenuhi peraturan pemerintah. Kualitas audit yang punya reputasi juga tidak dapat memoderasi hubungan komite audit dan nilai perusahaan.

Untuk penelitian selanjutnya, disarankan untuk memperpanjang periode pengamatan, sehingga dapat diperoleh lebih banyak jumlah observasi. Bagi penelitian selanjutnya, melalui koefisien determinasi (Adjusted $R$ Square) diperoleh -.02,7 persen dan sisanya 127persen dipengaruhi oleh variabel diluar peneliti, oleh karena itu penelitian selanjutnya disarankan untuk dapat menambah variabel-variabel lain. Sebaiknya penelitian mendatang tidak hanya menggunakan sampel perusahaan manufaktur sub sektor Industri Dasar dan Kimia saja, tetapi juga menggunakan perusahaan dari sektor industri lain.

\section{DAFTAR RUJUKAN}

Abdullah, M.S, Syed Zulfiqar Ali Shah and Arshad Hassan (2008), , Impact of Corporate Governance on Financial Performance of Firms: Evidence from Pakistan". The Business Review, Cambridge Vol. 11 Num. 2. pp. 282 - 290

Abdullah, M.S, Syed Zulfiqar Ali Shah and Arshad Hassan (2008), "Impact of Corporate Governance on Financial Performance of Firms: Evidence from Pakistan". The Business Review, Cambridge Vol. 11 Num. 2. pp. $282-290$

Aljufri, 2013," Pengaruh Corporate Governance Terhadap Nilai Perusahaan". Jurnal Ilmiah Ekonomi dan Bisnis Volume 1 No. 2 
Chan, Kam C. and Li, Joanne, Audit Committee and Firm Value: Evidence on Outside Top Executives as Expert-Independent Directors. Corporate Governance: An International Review, Vol. 16, Issue 1, pp. 16-31, January 2008.

Agoes, Soekrisno dan Ardana, Icenik. 2009 Etika Bisnis dan Profesi; Jakarta Salemba Empat

Ghozali, I. (2009). Analisis Multivariate Lanjutan Dengan Program SPSS.Semarang: Badan Penerbit Universitas Diponegoro.

Kumar, N., \& Singh, J. P. (2013). Effect of Board Size and Promoter Ownership on Firm Value: Some Empirical Findings from India. Corporate Governance: The International Journal of Business in Society Vol. 13 (1), 88-98.

Obradovich, J., \& Gill, A. (2013). The Impact of Corporate Governance and Financial Leverage on the Value of American Firms. International Research Journal of Finance and Economics, ISSN 1450-2887 Issue 91, 1-14.

Rachmawati, Andri dan Hanung Triatmoko (2007). Analisis Faktor-Faktor Yang Mempengaruhi Kualitas Laba dan Nilai Perusahaan. Simposium Nasional Akuntansi X. Makasar

Rouf, A. (2011). The Relationship between Corporate Governance and Value of the Firm in Developing Countries: Evidence from Bangladesh. The International Journal of Applied Economics and Finance Vol. 5 (3), 237-244.

Sulong, Z., \& Nor, F. M. (2008). Dividends, Ownership Structure and Board Governance on Firm Value:
Empirical Evidence from Malaysian Listed Firms. Malaysian Accounting Review Vol. 7 (2), 2008.

Siregar, Verinika N.P. dan Utama, Siddharta. (2005)," Pengaruh Struktur Kepemilikan, Ukuran Perusahaan dan Praktek Corporate Governance Terhadap Pengelolalaan Laba (Earnings Management), SNA VIII Solo, 15 - 16 September 2005

Tornyeva, K., \& Wereko, T. (2012). Corporate Governance and Firm Performance: Evidence from the Insurance Sector of Ghana. European Journal of Business and Management Vol. 4 (13), 95-112. 